\title{
THE STATUS AND POSITION OF THE VATICAN AND THE POPE AT INTERNATIONAL LAW: TRYING TO FIT A RELIGIOUS SQUARE PEG INTO A LEGAL CIRCLE?
}

\author{
Sipho Nkosi \\ BJuris LLB LLM Cert in Sports Law \\ Lecturer, University of Johannesburg
}

\section{SUMMARY}

The final word has not been spoken on the position and status of the Vatican; nor have the intricacies and complexities of its relationship with the Holy See been exhaustively ventilated. In the present writer's view, the debate as to whether the Vatican, or the Holy See, meets the requirements for statehood will rage on into the future. However, this article does not pretend to be definitive. It merely seeks to demonstrate how international-law concepts and phenomena are being stretched (sometimes beyond their limit) in order to accommodate the Vatican. The Vatican does not meet the minimum requirements for statehood; but it continues to be accorded, by the community of nations, the kind of recognition that more deserving entities such as Taiwan, the Palestine and Somaliland are being denied. Its officials and functionaries enjoy sovereign immunity in the courts of fully-fledged nation states which those of the aforementioned nascent states do not enjoy.

\section{$1 \quad$ INTRODUCTION}

There are many entities that enjoy privileges, protection and recognition at international law. It therefore becomes important to define them in precise legal terms. ${ }^{1}$ However, it should be borne in mind that international law, as a discipline, primarily deals with the rights, duties and responsibilities of

\footnotetext{
However, as Shaw International Law (2008) 45 puts it: "International law reflects first and foremost the basic state-oriented character of world politics. Units of formal independence benefiting from equal sovereignty in law and equal possession of all the attributes of statehood have succeeded in creating a system enshrining such values." But, it is also important to note that international law is not concerned only with the characteristics, rights and obligations of states; see Hay Federalism \& Transnational Organizations: Patterns for New Legal Structures (1966) 18 where he says: "International legal personality may be defined as the legal capacity ... of an entity, with or without the characteristics of a state, to participate in the international legal community by having rights and duties attributed to it by international law." (author's own emphasis); and see also Klabbers An Introduction to International Institutional Law (2002) 83, who emphasizes the point that international organizations are in a class of their own, and deserve to be treated differently.
} 
states. ${ }^{2}$ For that reason, it is necessary to determine which entity is a state and which one is not. Such an exercise is usually undertaken with the view to understanding the real juridical nature and position of that particular entity in relation to other similar entities; and whether it - together with its officials - is a bearer of rights, responsibilities and obligations at international law. Since 1929, when it was established, the Vatican ${ }^{3}$ has been the subject of a great deal of debate and controversy. In the main, the debate and controversy have really been about its legal status and position in terms of international law; and about the recognition it continues to enjoy from the community of nations. ${ }^{4}$ Brown captures the nub of the problem very well when he says: "The Roman Catholic Church is a unique theo-political entity. ${ }^{5}$ It enjoys the dubious status of being recognized throughout the world as both a religion and a sovereign nation-state. The latter has been the basis of extending United States diplomatic recognition to the Vatican, and allowing the church's political wing - 'The Holy See' - to occupy a powerful position in international bodies, including the United Nations. This in turn has permitted the church to have a disproportionate voice in world affairs ..."6 (author's own emphasis). However, as with most of the works on this subject, it is difficult to discern from the passage what the difference between the Vatican and the Holy See (Sancta Sedes) really is. ${ }^{7}$ The one view is that these are two sides of the same construct in much the same way as the two-headed Roman god Janus was. ${ }^{8}$ The other one is that the two entities are distinct and separate, and should be treated as such at international law. ${ }^{9}$ The latter view seems to suggest that, while the Vatican is a state, the Holy See is just a continually morphing non-state entity which

2 Dugard Introduction to International Law (2005) 1; Starke Introduction to International Law (1977) 66 and 106; and $c f$ Klabbers 42-43, who argues that "subject", in this context, is "a relative notion, the precise contents of which may differ from subject to subject and even between various subjects of the same category".

3 Oftentimes, "the Vatican" and "the Holy See" are used interchangeably. However, as will be shown below, the Vatican refers to the residual territory of what was the Papal States during the 19th century; and the Holy See refers to all the organs and the structures through which the Pope interacts with the international community - Shaw 243-244 and Currie, Forcesse and Oosteveldt International Law: Doctrine, Practice, and Theory (2007) 163-176; Oppenheim International Law: A Treatise (1947) 230-230; Doe v Holy See 555 F. 3d 1066 CA 9 (Or.) (2009) 2592-2593; and Holy See $v$ Starbright Sales Enterprises Inc ILR (1994) 163 165. For the sake of brevity and convenience, "the Vatican" will be used in this article, unless the context dictates otherwise.

4 Brownlie Principles of Public International Law (2008) 64; Shaw 243-244; and Currie et al 166-167.

5 Ironically, "theocracy", in itself, creates the impression that the Vatican has a fully-fledged government in the same mould as that of Iran (an Islamic state) which meets all the international-law requirements for statehood.

6 See Brown www.hartford-hwp.com/archives/67/273.html. "Efforts begin to retain Vatican's special status at the UN" accessed 10-01-2009; see also Denza Diplomatic Law (2008) 2930; and Currie et al 66.

7 Doe v Holy See supra 2592-2593; Holy See v Starbright Enterprises Inc supra 165; and Denza 29-30.

8 Ibid. But, cf Maluwa "The Holy See and the Concept of International Legal Personality: Some Reflections 198619 CILSA $12-3$ and 24; Maluwa "The Treaty-making Capacity of the Holy See in Theory and Practice: A Study of the Ius Tractum of a Non-state Entity" 198720 CILSA 155 155-157; Denza 29; and Currie et al 66.

9 Ibid. 
acts own its own at certain times, or on behalf of the Vatican, at other times. Maluwa who is proponent of this view-point says: "First of all, it will be reiterated that there are two entities which must be distinguished in this discussion: the Holy See itself and the State of the Vatican City ${ }^{10}$... Having made that observation we can conclude that all the sovereign or international acts which the Holy See performs can be grouped into those pertaining to the Holy See qua Holy See, and those undertaken by it as the sovereign authority over, and on behalf of, the Vatican State ...."1 He also refers to the Vatican as a "vassal state", ${ }^{12}$ which enjoys "token sovereignty"; ${ }^{13}$ and to the Holy See, as a non-state entity. It is, therefore, not very clear which of these two entities is capable of entering into international norm-creating treaties. ${ }^{14}$ Maluwa is really at pains to draw a clear distinction as to which of the two entities represents the other at international law. ${ }^{15}$ However, due to inadequacies and a lack of capacity in many areas of its existence, the Vatican, or the Holy See, depends on neighbouring nation states for its continued existence and survival. ${ }^{16}$ The better view is that the Holy See and the Vatican are one and the same thing: like two sides of a coin. ${ }^{17}$ The distinction - if it be - is no more than that which exists between the International Committee of the Red Cross and the International Red Cross, and the various national Red Cross societies. ${ }^{18}$ It is rather notional and illusory: a much of a muchness. There could never have been the Holy See without the Papal States, and vice versa. There can, therefore, be no Holy See without the Vatican. And, if it is accepted that the Vatican represents a diminutive version of the Papal States, it is easy to conclude that the Holy See and the Vatican are legally (and factually) intertwined. The one is a component or subset of the other. ${ }^{19}$ The notion that the one entity has a separate, distinct, existence from the other is difficult to sustain. In sum, the Vatican represents the remaining territorial vestiges of the Papal States, and the Holy See connotes and denotes the organs through which the Roman Catholic Church, and the Vatican itself, is governed, and by which all its international activities are performed. ${ }^{20}$ In other words, the former relates to the temporal, territorial aspects of the entity; and the latter refers to the ecclesiastical, spiritual, aspects. ${ }^{21}$ The Holy See represents the "episcopal jurisdiction of the Catholic Church in Rome, with its bishop being

\footnotetext{
Maluwa 198619 CILSA 24; Maluwa 198720 CILSA 162.

Ibid.

12 Maluwa 198619 CILSA 3 and 25, where he also refers to the Vatican as "an anomalous" entity.

13 Maluwa 198720 CILSA 161.

14 Maluwa 198619 CILSA 24-25; and Maluwa 198720 CILSA 162

15 He either does not provide any authority in support of his contention; and where he does, it is very thin - Maluwa 198619 CILSA 25-26; and Maluwa 198720 CILSA 159.

16 Shaw 200.

17 Doe v Holy See supra 2592-2593; and Maluwa 198619 CILSA 25.

18 The functions and activities of these national societies are co-ordinated by a League; and the different Leagues hold a conference once every four years (see Shaw 1200-1202).

19 Denza 29 (and the authorities cited therein).

20 Oppenheim 230-323.

21 Denza 29; and Maluwa 198619 CILSA 3.
} 
the Pope". ${ }^{22}$ Even Maluwa concedes that when the Holy See acts on behalf of the Vatican "it acts with plenary capacity 'derived' from the Vatican ...,23 Practically, the Vatican is now just a miniscule relic of the famed Papal States. It comprises just a few tracts of land within the city of Rome $;{ }^{24}$ and the Holy See still remains the organ through which it interacts with the international community. ${ }^{25}$

\section{A BRIEF HISTORICAL BACKGROUND}

For many centuries, the popes have played a very important role in shaping the religious and political outlook of the world. ${ }^{26}$ Through the Holy See, they engaged in international affairs. ${ }^{27}$ They sent and received envoys through and active and passive ligation. ${ }^{28}$ However, in the course of time, their territorial - as opposed to spiritual - powers have been incrementally curtailed and severely restricted by the government of Italy. ${ }^{29}$ Up until the 19th century, the status and position of the Pope was the same as, and equal to, that of any monarch in Europe. ${ }^{30}$ Through the Holy See, he engaged in international affairs on a par with other states. ${ }^{31}$ However, in 1860 the Papal States were annexed by Emperor Victor Immanuel's army. ${ }^{32}$ Only the city of Rome, and the eastern regions of what is now known as Italy, remained under the control of the Pope. ${ }^{33}$ In 1871, Emperor Immanuel's army annexed even Rome itself; and it was later declared the capital of Italy. The powers and authority of Pope Pius XI - who was the incumbent then - were virtually abrogated. ${ }^{34}$ It was, however, impossible to ignore the Pope in his capacity as the spiritual head of the Catholic Church. This seems to be the reason why the Holy See, the ecclesiastical component of this entity, has survived and outlived the Papal States. ${ }^{35}$ The Vatican, on the other hand, is a far cry from what it used to be. It is, in reality, a truncated version of its former self. It has now been reduced to small patches of land which are nestled on the Vatican Hill on the right bank of the

22 Even though the court was conscious of its judicial obligation in this regard, it did express its reservations about the true international status of the Doe v Holy See supra 2591. However, cf Maluwa 198619 CILSA 3 and 24.

23 Maluwa 198619 CILSA 25.

24 According to Art 3 of the Lateran Treaty, 1929, Italy recognizes "the Vatican City as appertaining to the Holy See". See Currie et al 165 , where the authors refer to the Holy See as "the government of the Vatican". However, cf Maluwa 198619 CILSA 3-4, 23 and 25.

25 lbid

26 Maluwa 198619 CILSA 29; and Maluwa 198720 CILSA 161.

27 Denza 29; Maluwa 198619 CILSA 2-3.

28 Maluwa 198619 CILSA 29.

29 Denza 29; Oppenheim 226-227; and Holy See v Starbright Sales Enterprises Inc supra 165.

30 Oppenheim 226; and Holy See $v$ Starbright Sales Enterprises Inc supra 165.

31 Maluwa 198619 CILSA 2-3; and Denza 29.

32 Ibid.

33 Oppenheim 227.

34 Ibid.

35 To this end, the "Law of Guarantee" (La Legge Delle Guarentigie) was passed on 3 May 1871. Its ratio legis was to clarify the prerogatives of the Pope and the Holy See, and to regulate the relationship between the Catholic Church and the state of Italy. 
Tiber River within the city of Rome itself. ${ }^{36}$ It now consists of a very small territory, with a largely foreign population and with virtually no political power to speak of. ${ }^{37}$ To all intents and purposes, the Vatican and the Pope have become an integral part of the state of Italy: its territory, population and administration. ${ }^{38}$ As will be indicated below, an attempt was made in 1929 at ameliorating the position of the Pope. A document, ${ }^{39}$ comprising a treaty, a financial convention ${ }^{40}$ and a concordat, ${ }^{41}$ was signed by Benito Mussolini and a representative of the Pope, Cardinal Pietro Gasparri. This composite document is now known as "the Lateran Treaty". In 1984, another concordat whose main objective it was to ratify the Lateran Treaty, and to curtail the powers and influence of the Catholic Church even further. ${ }^{42}$ And, to this day, the Vatican - and the Church - continues to resist these encroachments on its perceived territorial and spiritual terrains. ${ }^{43}$

\section{THE REQUIREMENTS FOR STATEHOOD}

Now that the historical background and the composite nature of the Vatican have been dealt with, it becomes necessary to examine the requirements for statehood in relation to it. For convenience, and for the purpose of avoiding confusion, "the Vatican" will be used in this article. The Montevideo Convention on the Rights and Duties of States of $1933^{44}$ sets out the requirements for statehood, and they are: (a) a permanent population; (b) a defined territory; (c) a government; and (d) the capacity to enter into relations with other states. ${ }^{45}$ Ordinarily, these requirements help us determine the nature and extent of a particular entity's statehood and sovereignty. ${ }^{46}$ In relation to the Vatican, it is also important to discuss these requirements in relation to, and in the context of, jus cogens. ${ }^{47}$ This exercise will help indicate whether the Vatican is a creation of international law, or just a product of political expediency and ideology. In Doe $v$ Holy See, Berzon J

36 In effect, the Vatican is a "state" which exists within a city of another state, very much like the Sandton City Mall which is located within the city of Johannesburg.

37 After all, it is a religious organization (Doe v Holy See supra 2593). However, cf Maluwa 198720 CILSA 164-165; and Currie et al 167

38 Art 6 of the Lateran Treaty; and Shaw 200.

39 From the preamble, and Art 2, it is clear that the main objective of the Treaty was to recognize "the sovereignty of the Holy See in international matters ..."

40 It provides for the compensation or reparations for the damage that the Vatican had suffered during Emperor Immanuel's reign.

41 Like the Law of Guarantees, it was intended to regulate the relationship between the government of Italy and the Roman Catholic Church.

42 See fn 20; and see also Maluwa 198720 CILSA 165.

43 lbid.

44 This is a convention which was signed by the United States of America and 15 Latin American states. Its provisions have become part of the binding body of international customary law, including jus cogens, and have become inviolable (see Shaw 125-127).

45 Some commentators are of the view that respect for human rights and self-determination should be added as requirements for statehood. However, this view has not seen the light of day (see Dugard 128-130).

46 This concept is used interchangeably with "independence".

47 This concept came into the international-law lexicon in 1980 when the Vienna Convention on the Law of Treaties came into operation. It refers to a set of inviolable rules of international law (Shaw 124-125). However, cf Dugard 43. 
pointed to the crux of the problem, when she said: "I recognize that the Holy See's dual role as not only a sovereign but also the head of a worldwide church gives this case a peculiar complexion. But that sense of oddity comes about because the Holy See is a sovereign of an unusual kind."

\section{Permanent population}

International law does not require a particular minimum, in terms of size, for a particular entity to be regarded as a state. ${ }^{49} \mathrm{It}$ is for that reason that microstates $^{50}$ such as the Seychelles - which have a population of about 80000 people - are accorded the same rights, and incur the same duties, ${ }^{51}$ as India and the United States of America - which have populations of about 1 billion and 310 million people respectively. ${ }^{52}$ This, in effect, means that the size of an entity does not count for much where the requirements for statehood are concerned. There is no need for there to be any congruence between the particular entity's acreage and its rights - and duties - at international law. Nor should there be any proportionality between its duties and the number of people who live within its territorial limits. ${ }^{53}$ The Vatican has never, at any one time in its history as such, had a population of more than 12000 people within its precinct. The population consists largely, of foreigners who cannot even become its nationals. ${ }^{54}$ Nor is there any semblance of permanence in their residence there. The population consists of religious figures and functionaries who, in turn, acquire citizenship of the Vatican merely on the basis of their being employed by there (jus officii). ${ }^{55}$ This goes against the tenets of municipal and international law, in terms of which citizenship derives from birth (jus soli), descent (jus sanguinis) or naturalization. ${ }^{56}$ This version of citizenship is even extended to the parents, spouses and descendants of these officials. ${ }^{57}$ However, it is important not to confuse citizenship with nationality. Nationality derives solely from birth, and never changes when the person changes his or her domicile or residence. ${ }^{58}$ And,

48 See Doe $v$ Holy See supra 2592-2593.This is an indication of the kind of misgivings that most judges have about the legal nature and status of the Vatican.

49 Currie et al 167; Brownlie 64-65; Dugard 83; and Doe v Holy See supra 2592-2593.

50 But, states such as Lichtenstein were denied the status of statehood precisely for being too small in terms of their territorial extent. This, it seems, was intended to discourage miniscule entities from being treated as fully-fledged states (Oppenheim 232). However, cf Dugard 83.

51 This concept refers to the acknowledgement by the nation states that a particular entity meets all the requirements for statehood. However, recognition, without more, does not invest an entity with statehood (Dugard 51-58); and Brownlie 64-65.

52 Currie et al 167; and Dugard 83. According to the 2010 Census, the population of the United States is estimated to be about 310 million http//geography.about/od/a/obtainpopulation data/a/uspopulation.htm.

53 As indicated above, it should be noted that there is now a move to discourage so-called microstates or mini-states from qualifying for statehood. It is believed that these entities are not in a position to carry out most of the obligations that are imposed on nation states by international law (Shaw 195); and Oppenheim 232. However, cf Dugard 83.

54 They do however, enjoy citizenship on the basis of being employees or officials of the Vatican (jus officii) (see fn 20 above).

55 See fn 20; and see also Shaw 244.

56 See Art 9 and 21 of the Lateran Treaty.

57 See fn 20 above.

58 Ibid. 
even if one is prepared to assume that the Vatican is a fully-fledged state, it is difficult to imagine the ever-transient personnel of the Roman Catholic Church becoming nationals of the Vatican. This is because nationality, unlike citizenship, is immutable. ${ }^{59}$ Moreover, these officials acquired citizenship when their employment with the Vatican is terminated. ${ }^{60}$ However, if they should lose their original citizenship - or that of the Vatican - then, they acquire Italian citizenship. ${ }^{61}$

\section{Defined territory}

As indicated above, this is one requirement of statehood which the Vatican fits snugly into. It relates to the extent of its land and acreage. ${ }^{62}$ It is not necessary for the territory of an entity to be a continuum of land and water for it to be a state. Nor do its boundaries need to be settled or free from any dispute. ${ }^{63}$ The fact that the territory of the Vatican is a mere .44 squarekilometres $^{64}$ in extent is not necessarily detrimental to its supposed aspirations of becoming a nation state. ${ }^{65}$ Although its territory is now a negligible fraction of what its precursor, the Papal States, was in the 19th century, the territorial extent and boundaries of the Vatican remain clearly definable; and its constituent parts remain easily determinable. ${ }^{66}$ And, the fact that it is virtually a part of the city of Rome - which is itself the capital city of the sovereign state of Italy - does not necessarily count against it being a state. ${ }^{67}$

\section{Government}

This requirement entails that there be an effective, and independent, ${ }^{68}$ government which has full control over the territory it is supposed to operate in; and to which members of the population owe habitual allegiance and

59 Unless the individual concerned becomes stateless. It is important to note that, while citizenship pertains to the constitutional, internal, relationship between the individual and the state, nationality relates to the external relationship between the individual, his state of origin, and the rest of the community of nations (Dugard 282-283). However, cf Brownlie 388-389.

60 There seems to be no possibility of their children obtaining citizenship of the Vatican through birth, descent or naturalization, let alone nationality. However, they do qualify to become citizens of Italy if they lose their original citizenship (see fn 20 above); and see also Art 9 and 21 of the Lateran Treaty.

61 Art 9 of the Lateran Treaty.

62 See fn 20.

63 Dugard 83; and Shaw 199.

64 Or 108.7acres.

65 Currie et al 167; Oppenheim 232; Dugard 71; and Doe $v$ Holy See supra 2592-2593.

66 They are protected in terms of the provisions of Art 3,14,15 and 16 of the Lateran Treaty.

67 See Doe $v$ Holy See supra 2591.

68 In this context, independence (or sovereignty) refers to what Hay calls the ability of an entity to demonstrate "internal supremacy and external independence". In other words, it is the entity's ability to govern (see Hay 19); see also Crawford "Israel (1948-1949) and Palestine (1998-1999): Two Studies in the Creation of States" in Goodwin-Gilland and Talmon (eds) The Reality of International Law (1999) 95 113. But, cf Currie et al 167-169. 
obedience. $^{69}$ This presupposes an entity which has all three arms of government - the legislature, executive and the judiciary - being effective within the length and breath of its territory. ${ }^{70}$ And these arms of government must be so effective as to make such an entity a significant role-player in the international "law-making process" despite its illegitimacy or similar legal disability. ${ }^{71}$ This point should not, necessarily, be construed to mean that such a government should not, in any way, be dependent on some or other nation state for strategic, economic or material support. ${ }^{72}$ An examination of the organs of governance within the Vatican, and their relationship inter se might help determine whether it has an effective government or not. First, the legislature comprises of the unicameral Pontifical Commission whose members are appointed by the Pope and serve in that capacity for a period of five years. ${ }^{73}$ At the apex of the Commission is a president who is immediately below the Pope in rank. ${ }^{74}$ The actions of the Commission always have to be approved by the Pope. Its powers are limited to making laws on local security, transportation and records. ${ }^{75}$ To have force and effect, these laws have to be published in the Acta Apostolicae Sedes. ${ }^{76}$ Secondly, there is the Secretariat of State whose role it is to implement the decisions of the Pope and the Pontifical Commission. Security within the precincts of the Vatican is provided by the Copa della Gendameria which resembles a police force. ${ }^{77}$ There is also the Pontifical Swiss Guard which provides personal security to the Pope himself. ${ }^{78}$ This is because the Vatican does not have armed forces (an army) of its own. ${ }^{79}$ Third, the judicial functions are performed by a tribunal, a Supreme Court, and an appeal court. $^{80}$ Fourth, by virtue of his primordial position as the bishop of the diocese of Rome, the Pope is "the ex officio head of State and head of the government of the Vatican" ${ }^{81}$ However, it is important to note that the Pope often overrides these structures, and exercises all the legislative, executive and judicial powers himself, albeit with the help of his inner council - the Roman Curia. ${ }^{82}$ The structures themselves, such as they are, do not

69 Hay 19; Starke 107; and Dugard 83-84.

70 Hay 19; and Currie et al 213-214.

71 It is one thing to acknowledge the existence of a government whose legitimacy is in doubt, but it is quite another to grant recognition to an entity, like the Vatican, which does not even have any semblance of statehood (Crawford 113). However, cf Currie et al 165.

72 The Vatican does not seem to have capacity to govern. It appears to have abdicated the power to do so, in favour of Italy (Shaw 200). However, cf Doe v Holy See supra 2592-2593.

See fn 20 above.

74 Ibid.

75 Ibid. This does not, in any way, help to distinguish the Vatican from any other voluntary association or religious organization.

76 This is something akin to the Government Gazette.

77 See fn 20 above.

78 This has been a standing agreement between the government of Switzerland and the Papal States - and later the Vatican - since 1506 when Pope Julie II was the pontiff. And, as indicated above, Italy is responsible for safety and security within the Vatican (see fn 20 above).

79 See fn 20 above.

80 Ibid.

81 Ibid.

82 Very much like a European monarch of old (see fn 20 above). 
necessarily set the Vatican apart from other religious organizations or political parties or social clubs. ${ }^{83}$ Nor do they convert the present-day Pope into a monarch - absolute or constitutional. ${ }^{84}$ From the provisions of the Lateran Treaty it is clear that Italy has always been, and still is, militarily responsible for the security and defence of the territory of the Vatican. ${ }^{85}$ The Swiss Guard and the Italian Police, on the other hand, are responsible for general police duties. Serious crimes such as robbery and murder, which are committed in and around the Vatican, are dealt with by the courts in Rome, Italy. ${ }^{86}$ However, much as the Vatican may wish to punch above its weight, it does not have the wherewithal to do it. Its position and status, at international law, is on all fours with that of Liechtenstein, San Marino, Andorra and the apartheid-sponsored "states" of Transkei, Bophuthatswana, Venda and Ciskei (the "TBVC states"). ${ }^{87}$ The TBVC states were completely dependent on South Africa, and their government, for infrastructure, defence, foreign affairs, budgets and other functions. ${ }^{88}$ For that reason, it is difficult to imagine a time when the actions of the Pope - and those of the other officials and functionaries within the Vatican - would develop into "state practice" which would, in turn, mutate into binding rules of international customary law. ${ }^{89}$ On this point, the Vatican does not seem to have an effective government in the international-law sense.

\section{Capacity to conduct international relations}

Since the fifth century, and during the existence of the Papal States, the Pope participated in international relations with other states through papal envoys, also known as nuncios. ${ }^{90}$ There were also apostolic delegates, who represented the Pope in those states where the Catholic Church had a presence; and who ensured that there was continuous contact between the Vatican and the Catholic Church. Their position and status is the same as that of consuls. ${ }^{91}$ There does not seem to have been any change in this regard. Despite the fact that the size of its territory has been dissipated and

83 Starke 122-123.

84 Before the annexation of the Papal Sates, the position of the Pope was akin to that of a European monarch (Holy See $v$ Starbright Sales Enterprises Inc supra 168-169); and Maluwa 198619 CILSA 2-3.

85 The provisions of Articles 22 allow for persons who have committed offences within the territory of the Vatican to be tried and sentenced by Italian courts. The Article also contains "one-way extradition" provisions which oblige only the Vatican "to hand over to the Italian State all persons who may have taken refuge within the Vatican City". There is no similar obligation on the Vatican to reciprocate. This is because of a lack of capacity on its part to perform certain essential governmental function; and see also Shaw 200.

86 See fn 20 above.

87 Shaw 202-203; and Oppenheim 230-232.

88 Shaw 202-203; and Dugard 83-88.

89 This can only happen through the "norm-creating" activities (state practice) of the departments of an effective government of a nation state (Shaw 8). However, cf Maluwa 198619 CILSA 15-16; and Maluwa 198720 CILSA 161-163.

90 The status of the nuncios is the same as that of ambassadors in international law (see fn 20 above).

91 See fn 20 above. 
transmogrified beyond recognition, ${ }^{92}$ the Vatican still continues to conduct international relations with state entities, as though it is one itself. ${ }^{93}$ For instance, in central and western Europe and South America, where the Catholic Church enjoys a very strong presence, the nuncios occupy a higher position and status than ordinary ambassadors. ${ }^{94}$ After presenting their credentials to the head of state, they occupy a position similar to that of the dean of the diplomatic corpse. ${ }^{95}$ However, it is important to note that the Vatican does not have a diplomatic corpse or a real, conventional, diplomatic service to speak of. ${ }^{96}$ This is because it is not capable of hosting embassies within its own territory. All foreign embassies are located in Rome. ${ }^{97}$ At first glance, this may seem to be related only to the acreage of the Vatican. But on closer scrutiny, it points to the fact that the Vatican relies, wholly, on Italy for the proper conduct of its own international relations. ${ }^{98}$

\section{Recognition}

Recognition is one of the most important, but controversial, phenomena of international law. It signifies acknowledgement by "the community of States that an entity possesses the necessary international legal personality and is entitled to share in the benefits of and to subject itself to the obligations of international law as a State". 99 It is usually a matter of intention on the part of the recognizing state(s), and may either be express or implied. Primarily, recognition is more a matter of policy than it is of law; it is premised on the need to derive some direct or indirect economic, political or strategic benefit from the entity being recognized. ${ }^{100}$ As indicated above, the Vatican came into existence as a result of a treaty that the Pope and Benito Mussolini signed in 1929 - the Lateran Treaty. ${ }^{101}$ Just like an erstwhile protectorate being recognized as a nation state by its former colonial power in terms of a statute, the Lateran Treaty was a clear manifestation of the intention, on the part of Italy, to recognize the Vatican as a sovereign state..$^{102}$ In other words, the creator and sponsor of the Vatican was the first state to recognize it.

92 Ibid.

93 See fn 20 above; and see also Denza 29-30. What is ironical is that the Vatican has even adopted the so-called "one China" policy, thereby denying the existence of Taiwan as a state. The international community is, itself, prepared to recognize the Vatican, which barely meets the requirements for statehood; but it is not prepared to extend the same courtesy to the nascent states of Taiwan, the Palestine and Somaliland.

94 See fn 20 above.

95 Ibid.

96 Ibid.

Ibid.

98 Shaw 244.

99 Dugard 5 and 1-58 (emphasis as in the original). However, the recognition of an entity by the states should be distinguished from its admission to the United Nations in terms of Art 5 (read with Art 4) of its Charter. Moreover, the Vatican is merely a "non-member state" (see also Currie et al 166-1667).

100 However, the entity that is being recognized must (outwardly) display full independence (Hay 19); Starke 149-150; and Crawford 113.

101 See the preamble to the Lateran Treaty (and Art 1 thereof).

102 Ibid. 
Some decades later, other states ${ }^{103}$ including the United Kingdom and the United States of America, also joined in recognizing Vatican's presence and existence among them. Its statehood and sovereignty were formally acknowledged by the recognizing states. ${ }^{104}$ It was a declaration that it conformed to "the basic requirements of international law as to the creation of a state". ${ }^{105}$ Even though the act of recognition is not necessarily based on a particular format, it should, however, be reserved for those entities that approximate statehood, as it has recently happened in the case of South Sudan. ${ }^{106}$ It should be applied sparingly, and with a great deal of circumspection. ${ }^{107}$ Recognition should not be used to create a state where there was none before. ${ }^{108}$ Nor should it be denied to an entity that meets all the requirements for statehood. ${ }^{109}$ For instance, there is no sound principle except for extraneous considerations - on which the non-recognition of entities such as Taiwan, the Palestine and Somaliland is founded. ${ }^{110}$ Like South Sudan, these entities seem to be better placed, and much more prepared to govern their own territories properly, and to control their respective population effectively. ${ }^{111}$ However, despite not meeting most of the requirements for statehood, the Vatican continues to enjoy observerstatus within the United Nations, as a "non-member state". ${ }^{12}$ It may be argued that mere admission to the United Nations does not necessarily change a non-state entity ${ }^{113}$ into a fully-fledged nation state. However, considered with other factors, such admission might be one of the steps towards full statehood..$^{114}$ However, for the Vatican such a journey might be too long and arduous. First, the Vatican relies on neighbouring nation states for its general security needs and effective governance. ${ }^{115}$ Second, even though it enjoys the rights and privileges, as "non-member state" of the United Nations, it does not have the wherewithal to meet any of the

103 Denza 29-30; and Currie et al 166-167.

104 See the preamble to the Lateran Treaty; see also Crawford 96; and Currie et al 164-174.

105 Shaw 368-368; and Dugard 90-94. But, cf Starke 151.

106 See Klabbers and Lefeber "Africa: Lost Between Self-determination and Uti Possidetis in Brolman, Lefeber and Zieck (eds) Peoples and Minorities in International Law (1993) 54; see also Currie et al 167; and Cattan Palestinians, the Arabs and Israel (1969) 275.

107 See fn 106 above.

108 Ibid.

109 Ibid.

110 Taiwan, Somaliland and Palestine seem to be in this kind of predicament. Factually and legally, they seem to meet all the requirements of statehood, but remain unrecognized by the family of states (see Oppenheim 230-232); see also Shaw 237; Cattan 275; Currie et al 175-176; and Crawford 96 and 123.

111 Currie et al 167-169. It is important to note that on 14 July 2011 a new state, the Republic of South Sudan, became the 193rd member of the United Nations on 14 July 201, after seceding from the Sudan, and declaring its independence on the 9 July 2011.

112 In this regard, the United Nations seem to have exercised its authority, albeit ostensible, in terms of Art 4.2 of its Charter.

113 However, such an entity may be entitled to certain rights and privileges, such as access to the International Court of Justice, access to certain international agencies and participation at conferences summoned by the United Nations to adopt international conventions (Currie et al 165); and Starke 110-111.

114 See fn 111 above.

115 Shaw 200. 
correlative obligations. ${ }^{116}$ Third, it does not have a permanent and habitually loyal population over which to exercise political control within its own territorial limits. ${ }^{117}$ Fourth, the Vatican merely meets the requirements of a lesser entity - such as an international organization - and deserves to be governed and regulated by a "body of rules that may well be described as international constitutional law" ${ }^{118}$ Fifth, the fact that some of the organs of the Vatican perform what may conveniently be classified as legislative, executive or judicial functions, does not, in itself, transmogrify it into a fullyfledged state. ${ }^{119}$ As indicated above, it actually belongs to a category of entities which should be governed by the second tier of international-law rules and instruments. ${ }^{120}$ This is because international (religious) organizations, such as the Vatican, rightfully belong to this category; and their office-bearers need not even enjoy immunity from the jurisdiction of the courts of the host states.

\section{Statehood and jus cogens}

As indicated above, jus cogens is a set of obligatory and binding principles of international law which are not to be lightly derogated from. ${ }^{121}$ They are the "fundamental and superior values" which, through acquiescence and acceptance, have become the centre-piece of international customary law. ${ }^{122}$ As Shaw puts it: "The concept of jus cogens is based upon an acceptance of fundamental and superior values within the system and in some respects is akin to the notion of public order or public policy in domestic legal orders ... [These values and norms] require universal acceptance (and) recognition ... by an overwhelming majority of states, crossing ideological and political divides." ${ }^{123}$ They are not to be imposed on ideological or political minorities, for economic, political or strategic objectives. They should be a product of consistent observance and universal application of the provisions of treaties; and a consequence of persistent adherence to the rules international customary law over a considerable period of time. ${ }^{124}$ Therefore, in

116 See Art 4 and 5 of the Charter.

117 Starke 639-645; Hay 19; and Currie et al 168-169.

118 See Crawford 96; see also Hay 19.

119 Even though it still remains a subject at international law - Maluwa 198619 CILSA 11-12.

120 Shaw 45; Klabbers 83; Starke 639-644; and Hay 19. But cf Maluwa 198619 CILSA 7-12.

121 Dugard states his views on the matter as follows: "Today it is accepted that there are certain basic norms upon which the international order is founded and that these are peremptory and may not be derogated from under any circumstances ... An act in violation of a norm having the character of jus cogens is illegal, and is therefore null and void. This applies to the creation of states and to the acquisition of territory. States are under a duty not to recognize such acts under international law, and in accordance with the general principles of law" (99-100).

122 This phenomenon seems to be a departure from the principle of equality of the rules of international law; and has created a hierarchy of rules, with the jus cogens at the apex (Dugard 43).

${ }^{123}$ Shaw 127. However, cf Dugard 43 who says there is no agreement as to which rules should be categorized as jus cogens.

124 See Boyle and Chinkin The Making of International Law (2007) 236 who say: "Support for a rule created by a treaty, however universal, cannot by itself create instant law. A treaty can only create new law if it is supported by consistent and repetitive state practice over a period 
determining whether there is an emerging rule of ius cogens, which is deserving of observance and application by the community of nations, the following considerations should be taken into account: (a) there is no clear catalogue which sets out precisely what constitutes jus cogens; ${ }^{125}$ (b) the states themselves, as the primary subjects of international law, place a great deal of premium and primacy on the requirements for statehood, and other related rules of international law; ${ }^{126}$ (c) jus cogens flows from the rules of international customary law and the treaties whose provisions have attained the requisite superior status and binding force ${ }^{127}$ (d) international customary law, itself, flows from recognizable state practice which has been accepted, and consistently observed, by the majority of states over a considerable period of time; ${ }^{28}$ (e) and, to a great extent, such acceptance and observance must not have been imposed on political or ideological minorities - by the more powerful or wealthier states. ${ }^{129}$ It is also important to note that these "fundamental norms and values" still remain unmodified, and have not been changed by any rule of international customary law of the same character. ${ }^{130}$ Nor have they been abolished by a subsequent treaty which is in pari materia. ${ }^{131}$ The requirements for statehood are still at the pinnacle of international law; and as part of jus cogens, they remain inviolable. Consequently, any form of recognition which is in breach of these peremptory rules is a nullity. ${ }^{132}$ Recognizing and projecting the Vatican as a fully-fledged state is tantamount to using the exception to prove a general principle. And, as O'Connell puts it: "Premature recognition [of any entity] ... is an abuse of [international law] procedure."133 The breach becomes much more jarring when deserving entities, such as Taiwan, the Palestine and Somaliland, are inexplicably not accorded the same kind of recognition that the Vatican is enjoying. ${ }^{13}$

of time. That practice can in appropriate cases consist of acquiescence; or absence of inconsistent practice." See also Shaw 126. However, cf Dugard 43.

125 Shaw 126-127.

126 Ibid.

127 See fn 123 above.

128 Ibid.

129 The opposite of this would occur where less powerful states are of the view that a particular entity meets all the requirements for statehood and needs to be accorded recognition, as it happened when Zambia, Tanzania, Gabon and Ivory Coast indicated their intention to recognize Biafra's secession from Nigeria. The African Union is refusing to acknowledge Somaliland's intention to secede from Somalia and its wish to become a fully-fledged nation state. Its view is that secession will affect Somalia's unity and sovereignty (see Shaw 237); see also Brownlie 77-78; and Cattan 275.

130 Art 53 of the Vienna Convention on the Law of Treaties; and Shaw 125.

131 To the extent that the provisions of the Lateran Treaty purport to create a state out of the Vatican, they seem to have been abolished by those of the Montevideo Convention (Art 53); and Shaw 125. And, the practice of the nation states with regard to the Vatican qua state has not been consistent; nor has been acquiesced to by most of them.

132 O'Connell International Law for Students (1971) 51.

133 O'Connell 89. Paradoxically, the community of nations has found it easy to recognize the Vatican, but difficult to recognizes near-state entities such as Taiwan, the Palestine and Somaliland. It is even difficult to discern any substantive difference between South Sudan which was admitted by the General Assembly as the $193^{\text {rd }}$ member of the United Nations 14 July 2011 - and these entities.

134 See Shaw 234 and 237; see also Brownlie 77-78; and Cattan 275. 


\section{IMMUNITY AND THE VATICAN}

After examining the requirements for statehood, the role of recognition in international law and the peremptory nature and force of jus cogens, it becomes important to examine the concept of immunity ${ }^{135}$ with regard to the Vatican. This is because of the widespread allegations of sexual abuse against the Roman Catholic clergy, and the litigation they have spawned in many parts of the world, particularly, the United Kingdom and the United States. In international law, immunity refers to a bar to the authority of the courts of the one state from adjudicating on certain matters which involve sovereigns, government functionaries and the property of other states. ${ }^{136}$ This form of immunity is an incident of statehood. It is founded on the maxim par in parem non habet jurisdictionem. ${ }^{137}$ It is intended to ensure that nation states enjoy equal sovereignty and independence in relation to one another. ${ }^{138}$ But, as indicted above, it is difficult to imagine the Vatican sharing the same responsibilities and obligations as the nation states themselves. ${ }^{139}$ In the recent past, the courts have had the opportunity to deal with sovereign immunity as it pertains to the Vatican. For instance, in Holy See $v$ Starbright Sales Enterprises $I n c^{140}$ where the petitioner, Starbright Sales Enterprises Inc, instituted a civil action against the respondent, the Holy See, for breach of a contract of sale of land, and asked for specific performance and damages. The Supreme Court in Manila, the Philippines, said that because the Holy See was a sovereign state, its officials enjoyed immunity in that country, and that the courts had no jurisdiction over them. ${ }^{141}$ It is important to note that the Philippines do not have a piece of legislation that is similar to the United States' Foreign Sovereign Immunity Act, $1976 .{ }^{142}$ In O'Hair $v$ Woyjtila; Andrus, ${ }^{143}$ where an application was made for an injunction prohibiting the Pope, (Woyjtila), from leading a Mass at "The Mall" in the city of New York, the court held that the courts in the United States have no jurisdiction to issue process against the Vatican. ${ }^{144}$ However, it is

135 This concept is also referred to as the doctrine of "inadmissibility or non-justiciability" (see Brownlie 324-325).

136 This is known as sovereign immunity; and it is based on "weighty considerations of public policy, international law and comity" (see Liebowitz v Schwatz 19742 SA 661 (T) 661 H662A).

137 See Brownlie 325; and see also Dugard 239.

138 However, one cannot ignore the obvious inequalities in the strengths and the capacities of the different states; or discount the responsibilities and obligations that rest on them (see Starke 125).

139 Ibid.

140 Supra 163

141 See Holy See $v$ Starbright Sales Enterprises Inc supra 165, where the court expressed its reservations about the nature and status of the Vatican, but said that it did not wish to usurp the powers of the executive arm of government. This seems to be the common refrain among judges who have had to adjudicate on matters such as this; and see also Doe $v$ Holy See supra 2592-2593.

142 US 28 1976. States such as Australia, South Africa and the United Kingdom have similar pieces of legislation.

143 F. 2d 1018 (1979).

144 In 2009, the 9th Circuit Court in California, reached the same conclusion in Finkelstein $v$ Vatican (2009) http://normanfinkelstein.com/holocaust.html accessed 2009-12-29. 
the epoch-making judgment in Doe $v$ Holy See ${ }^{145}$ which is likely to bring about a significant change in the American jurisprudence in this regard. In this article, however, the case is discussed merely to indicate how differentially the Vatican is being treated by the international community; and how it is being accorded the rights and benefits which other kindred entities do not enjoy at international law.

\section{Doe v Holy See}

In the case of Doe $v$ Holy See the Appeal Court for the 9th Circuit Court in Oregon had the opportunity to determine whether it, and the district court below, had the requisite jurisdiction to hear a civil matter involving a Roman Catholic priest, one Father Andrew Ronan, who was alleged to have molested Doe, the plaintiff. Doe was fifteen when the alleged acts were committed. Ronan, who has since passed away, had been a priest in Ireland, and was later transferred to Our Lady of Benburb under the authority of the Bishop of Chicago, and then to the St Albert's Church in Portland, Oregon. The transfers were necessitated by Ronan's penchant for "harmful sexual contact" with small boys at the parishes where he worked. Doe instituted action against the Holy See, the Archdiocese of Portland, the Bishop of Chicago and the Order of the Friar Servants, to which Ronan belonged. The Bishop, the Archdiocese and the Order were cited as "agencies or instrumentalities" of the Holy See. ${ }^{146}$ The legal question was whether the heads, under which the matter was argued on behalf of Doe in the district court, and in the Appeal Court itself, were covered by the statutory exceptions as set out in the FSIA. Put otherwise, the question was whether the district court had jurisdiction to adjudicate on the matter involving Ronan, the Holy See, the Archdiocese, the Bishop and the Order in terms of the FSIA. Section 1605 of the Act creates a general exception: a foreign state shall not be immune from the jurisdiction of the courts of the United States, and those of its constituent states where the claim is based on a "commercial activity carried on in the United States by a foreign state; or upon an act performed in the United States in connection with a commercial activity of a foreign state elsewhere ... or in which monetary damages are sought against a foreign state for personal injury or death ... caused by the tortuous act of that foreign state or any official or employee of that foreign state while acting within the scope of office or employment ..." The district court (below) held that all Doe's claims, ${ }^{147}$ except for the one

\footnotetext{
${ }^{45}$ Supra.

${ }^{146} \mathrm{~S} 1603(\mathrm{a})$ does not define what a "foreign state" is. It merely states that the term includes "a political division, an agency or instrumentality of such a foreign state". It is does not deal with substantive issues. It is just a jurisdictional piece of legislation which sets out the circumstances in which civil proceedings may be instituted against these entities. In terms of $\mathrm{s} 1608$, the decision as to which entity is to be recognized as a state, and be treated as such when court process is to be served, lies with the State Department, the State Secretary and the Director for Special Consular Services; see also Doe v Holy See supra 2556; and Holy See $v$ Starbright Sales Enterprises Inc supra 165.

147 The other claims were based on the commercial activity exception and the tortuous injury exception.
} 
based on the fraud exception, fell within the statutory exceptions to immunity, and that it had the requisite jurisdiction to hear those claims.

\section{The majority judgment}

After considering the facts and evidence, the majority upheld the decision of the district court - in part - and put it thus: "Doe's ... claim based on Ronan's actions comes within the tortuous act exception. Doe has clearly alleged that Ronan was an employee of the Holy See, acting within the scope of his employment, when he molested Doe. We conclude, however, that Doe's claim against the Holy See for negligent retention and supervision [of Ronan] and failure to warn [the Archdiocese and Doe against Ronan's propensity for molestation] cannot be brought under the tort exception because they are barred by the FSIA's exclusion for discretionary functions ..."148 This was due, in part, to the fact that Doe had failed, through his pleadings, to rebut the presumption that the Holy See and Archdiocese of Portland, had a separate juridical existence from each other; or to demonstrate that the Holy See actually exercised "day-to-day control over the Archdiocese,",149 - under whose authority the Bishop of Chicago and Ronan were - when the alleged acts of molestation were committed against Doe. The Court was also of the view that Doe had failed to demonstrate that the Holy See had abused the separate existence of these entities in order to defeat the precepts of the law and to avoid liability. ${ }^{150}$ The majority, however, left open the question whether the conduct of the Holy See (and the Archdiocese and the Bishop of Chicago) vis-à-vis Ronan amounted to a "commercial activity" as provided for in the FSIA. They were also of the view that Doe's pleadings did not contain sufficient averments to indicate that the relationship between Ronan and the Archdiocese (and the Bishop of Chicago) amounted to a "commercial activity". ${ }^{151}$ Coming to the question whether, at all material times, Ronan was an employee, and whether he was acting within the scope of his employment with the Holy See (and the Archdiocese), the Court said that there are three requirements that needed to be considered and applied to the facts: (1) the act must have occurred substantially within the time and space limits authorized by the employment; (2) the employee must have been motivated, at least partially, by a purpose to serve the employer; and (3) the act must have been of a kind which the employee was hired to perform. ${ }^{152}$ Relying on the judgment in Fearing $v$

148 This is based on the provisions of $1605(\mathrm{a})(5)(\mathrm{A})$. This is because these provisions do not extend liability to a foreign state where the "claim is based upon the exercise or performance or failure to exercise or to perform a discretionary function regardless of whether the discretion be abused ..." In other words, Ronan acted on his own when he allegedly molested Doe; and was obviously not promoting the interests of the Holy See.

149 In this connection, the court referred to Flatow v Islamic Republic 308 F. 3d 1065 (9 ${ }^{\text {th }}$ Circuit) in which the facts were slightly different, and said that even though the Bank Sederat of Iran was created by the government, it was the General Assembly of Banks and the High Council of Banks in that country that exercised "day-to-day control" over it.

150 Ibid.

151 This is about the only point where Berzon J's minority judgment differs from that of the majority.

152 Doe v Holy See supra 2573. 
Buchner, ${ }^{153}$ the majority indicated that, where the tort (delict) is intentional, there is no need to prove requirements (1) and (2) of the test. Rather, the question should be whether the work that "the employee was hired to perform ... resulted in the [conduct] that caused plaintiff's injury". ${ }^{154}$ The majority of the court, then, came to the conclusion that Ronan had committed the alleged acts of molestation while he was acting "within the scope of his employment" with the Archdiocese. However, they held that the court did not have the jurisdiction to hear Doe's claim on the continued retention and supervision of Ronan by the Holy See, the Archdiocese and the Bishop of Chicago, or their failure to warn those who were likely to come into contact with Ronan about his propensity for molestation. This is because, the court said, Ronan's actions were discretionary and were, therefore, barred by the provisions of the FSIA. ${ }^{155}$

\section{The minority judgment}

In her minority judgment, Berzon $\mathrm{J}$, was of the view that the Court had jurisdiction to hear all the claims, bar one ${ }^{156}$ that Doe had brought before it. She concurred with the majority that Doe's fraud claim was not determinative of the issues at hand. She said that the majority had mischaracterized Doe's claim, and had treated the tortuous and commercial activity exceptions as mutually exclusive concepts. ${ }^{157}$ She also said that, at the time when Doe was allegedly molested by Ronan, the latter had an employment relationship with the Holy See, the Archdiocese and the Bishop of Chicago; and that the employment relationship was, itself, a commercial, non-sovereign, activity. She pointed out that it is not unheard of for a non-profit organization to engage in commercial activities. ${ }^{158}$ In other words, the activities of the Holy See, vis-à-vis Ronan, were not distinctly sovereign in nature. ${ }^{159}$ Berzon J also said that emphasis should be placed on the nature of activity that a particular entity engages in, not the motive with which it is undertaken. ${ }^{160}$ And, that it was during its employment relationship with Ronan that the Holy See negligently continued to retain his services, or failed to supervise him properly, or failed to warn people who were likely to come into contact with him about his propensity for molestation. She also pointed out that, even though the contract of employment may have been entered into outside of the United States, its terms were carried out in that state, albeit in part, by the Holy See through its agencies or instrumentalities; and that the court, therefore, had jurisdiction to hear all of Doe's claims except the one based on the fraud exception. The court's view was that the decision to commit a

153977 P. 2d 1163 (Or.) (1999) 1166.

154 Doe v Holy See supra 2575.

155 Doe v Holy See supra 2578.

156 The one based on the fraud exception. The court was of the view that the claim was not intertwined with the other claims, and was not determinative of the issues before it (Doe $v$ Holy See supra 2584).

157 Doe v Holy See supra 2587-2591.

158 Doe v Holy See supra 2588.

159 Doe v Holy See supra 2592.

160 Doe v Holy See supra 2590. 
crime is a discretionary, individual act which is not covered by the exceptions provided for in FSIA. ${ }^{61}$ In the present writer's view, the minority judgment is to be preferred. This is because Berzon J, in her judgment, gave a broader interpretation of "commercial activity" thereby narrowing down the unduly wide protection that the officials of the Vatican and members of Catholic clergy - and other state entities - are already enjoying. It is also hoped that the Supreme Court of the state of Oregon, or the Federal Court, will uphold the judgment (particularly the minority one) in its entirety thereby contributing to the development of international law in this regard.

\section{CONCLUSION}

From the aforegoing, it is clear that the final word has not been spoken on this topic. The discourse is far from over. There is still no clarity on the international status and position of the Vatican and the Holy See; nor is the literature (and case law) any more lucid on the nature of the relationship between these entities any clearer. It is even difficult to understand why international-law concepts have had to be stretched - in certain instances beyond recognition - to accommodate the Vatican. What cannot be ignored, however, is that the Vatican is a far cry from what its precursor, the Papal States, was in the 19th century. Its territorial extent and geographical configuration have changed quite drastically from what they were during that time. However, as it was the case during the Papal States, the Holy See itself remains a permanent constant of this entity, albeit in its truncated state. It is still the administrative organ through which the Catholic Church and the Vatican are governed. As indicted above, the Vatican and the Holy See are merely two sides of the same coin; or two mediums through which one person, the Pope, exercises his ecclesiastical (spiritual) and terrestrial (temporal) powers. Any reference to the one entity is, by extension, a reference to the other.

The Vatican - or the Holy See is now shorn of all the power, authority and the glory of old. It now has to rely on neighbouring countries, particularly Italy and Switzerland, for safety, security, defence and other related governmental functions. It is not different from any other international organization. Its present nature and capacity make it difficult to understand why international-law concepts, rules and phenomena have had to be stretched, sometimes beyond recognition, to accommodate the Vatican. It continues to be accorded recognition (as state) by the nation states, and to enjoy observer status as a "non-member state" at the United Nations. It is the present writer's view that this state of affairs amounts to a breach of ius cogens; and it is difficult to comprehend why more deserving entities, such as Taiwan, the Palestine and Somaliland, are not treated the same way. It is also very difficult to fathom why the Vatican, and its officials, continue to enjoy (statutory) sovereign immunity from the jurisdiction of the courts of fullnation states to the exclusion of these entities.

161 Doe v Holy See supra 2578. 